\author{
GRZEGORZ WIELGUS
}

Urząd Statystyczny, Kraków

\title{
Rozwój sektora małych i średnich przedsiębiorstw w Polsce
}

Na początku lat 70. w Europie, a w Stanach Zjednoczonych nieco wcześniej, dostrzeżono zalety małej i średniej przedsiębiorczości (MSP) oraz jej rolę w gospodarczym rozwoju państwa. W Stanach Zjednoczonych sektor MSP zyskał miano podstawy całej gospodarki, natomiast Japończycy sektor ten widzą jako element silnie rozwiniętej sieci kooperacji, efektywnie wspierający rozwój dużego przemysłu (Piasecki 1998, s. 101). W naszym kraju dopiero w latach 90. doceniono zalety tego sektora. Rząd podejmując konkretne działania dla wytyczenia drogi rozwoju oraz wsparcia tych poniekąd słabszych uczestników rynku, wdrożył następujące programy: w 1995 r. program „Małe i średnie przedsiębiorstwa w gospodarce”, w 1999 r. „Kierunki działań rządu wobec małych i średnich przedsiębiorstw do 2002” i w 2002 r. „Przede wszystkim przedsiębiorczość”.

Powszechny i równy dostęp obywateli do wielu gałęzi gospodarki, jaki przyniósł do Polski czas gospodarki rynkowej, stworzył duże szanse dla rozwoju prywatnej przedsiębiorczości. Zniesienie wielu barier prawnych, charakterystycznych dla gospodarki etatystycznej, ograniczających rozwój przedsiębiorczości, pozwolił obywatelom na tworzenie i rozwijanie własnych inicjatyw. Duża chłonność rynku na wszelkiego rodzaju dobra i usługi była dodatkowym czynnikiem rozwoju przedsiębiorczości. Był to okres wysokiej dynamiki wzrostu liczby przedsiębiorstw, a szczególnie małych i średnich. Przedsiębiorstwa tego sektora w okresie transformacji gospodarczej kraju w znacznej mierze przyczyniły się do ograniczenia wzrostu bezrobocia, rozwoju poszczególnych regionów, stały się znaczącym czynnikiem aktywizacji całej gospodarki.

\section{DEFINICJA MAŁYCH I ŚREDNICH PRZEDSIĘBIORSTW}

W niniejszym artykule do zdefiniowania małych i średnich przedsiębiorstw posłużono się definicją Ministerstwa Gospodarki, zgodną z ustawą Prawo działalności gospodarczej. Mówi ona, iż za małego uważa się przedsiębiorcę, który w poprzednim roku obrotowym: zatrudniał średniorocznie poniżej 50 pracowników oraz osiagnął przychód netto ze sprzedaży towarów, wyrobów i usług oraz operacji finansowych nie przekraczających równowartości w złotych 7 mln euro lub suma aktywów jego bilansu sporządzonego na koniec poprzedniego roku obrotowego nie przekroczyła równowartości w złotych 5 mln euro. 
Nie uważa się za małego przedsiębiorcy, w którym przedsiębiorcy inni niż mali posiadają więcej niż $25 \%$ wkładów, udziałów lub akcji, lub prawa do ponad $25 \%$ udziału w zysku, więcej niż 25\% głosów w zgromadzeniu wspólników (akcjonariuszy). Za średniego przedsiębiorcę uważa się przedsiębiorcę nie będącego małym przedsiębiorca, który w poprzednim roku obrotowym zatrudniał średniorocznie poniżej 250 pracowników oraz osiągnął przychód netto ze sprzedaży towarów, wyrobów i usług oraz operacji finansowych nie przekraczających równowartości w złotych $40 \mathrm{mln}$ euro lub suma aktywów jego bilansu sporządzonego na koniec poprzedniego roku obrotowego nie przekroczyła równowartości w złotych 27 mln euro. Nie uważa się za średniego przedsiębiorcy, w którym przedsiębiorcy inni niż mali i średni posiadają więcej niż $25 \%$ wkładów, udziałów lub akcji, lub prawa do ponad 25\% udziału w zysku, więcej niż 25\% głosów w zgromadzeniu wspólników (akcjonariuszy). W przypadku przedsiębiorcy działającego krócej niż rok o uznaniu przedsiębiorcy za małego lub średniego stanowi tylko wysokość średniomiesięcznego zatrudnienia za ostatni, pełny miesiąc działania przedsiębiorcy.

\section{DYNAMIKA WZROSTU}

Sektor, o którym mowa w niniejszym opracowaniu, charakteryzuje się wysoką dynamiką wzrostu, w przypadku liczby nowo zakładanych (rejestrowanych) przedsiębiorstw. W latach 1991-2001 (zob. tab. 1) liczba przedsiębiorstw z sektora MSP wzrosła z 494 tys. do ponad 3 milionów, dawało mu to praktycznie przez cały ten okres bardzo wysoki procentowy udział w rynku. Kształtował się on na poziomie 98-99,8\% udziału przedsiębiorstw uczestniczących w obrocie gospodarczym kraju. Należy jednak pamiętać, iż przedsiębiorstwa zarejestrowane to nie zawsze przedsiębiorstwa faktycznie działające.

Tabela 1. Udział i liczba MSP w gospodarce w Polskiej w latach 1991-2001

\begin{tabular}{|c|c|c|c|c|c|c|c|}
\hline Rok & $\mathbf{1 9 9 1}$ & $\mathbf{1 9 9 3}$ & $\mathbf{1 9 9 5}$ & $\mathbf{1 9 9 6}$ & $\mathbf{1 9 9 7}$ & $\mathbf{1 9 9 9}$ & $\mathbf{2 0 0 1}$ \\
\hline Udział w \% & $98,39 \%$ & $99,60 \%$ & $99,69 \%$ & $99,73 \%$ & $99,76 \%$ & $99,80 \%$ & $99,82 \%$ \\
\hline Liczba w tys. & 494,2 & $1.980,7$ & $2.093,1$ & $2.373,4$ & $2.546,4$ & $3.007,4$ & $3.319,9$ \\
\hline
\end{tabular}

Źródło: dane za lata 1991-1999: Instytut Wspierania Przedsiębiorstw; http://iwp.pl/material/k99_msp.htm; http://www.mg.gov.pl/struktur/WWW_MSP/Statystyka/MSP_Stat.htm; Kierunki działań rzqdu wobec matych i średnich przedsiębiorstw do 2002 roku;

http://www.mg.gov.pl/struktur/WWW_MSP/Polityka/Polit_MS.htm; dane za rok 2001: Zmiany

strukturalna grup podmiotów gospodarki narodowej w 2002 r., GUS, Warszawa 2003, s. 50

W roku 1999 można zauważyć, iż dynamika wzrostu liczby przedsiębiorstw została zahamowana, mogło to być powodem m.in. polityki gospodarczej naszego kraju oraz recesji w gospodarce światowej. Obecnie liczba powstających przedsiębiorstw nie jest już taka wysoka w porównaniu z latami ubiegłymi, jednak jest to niewątpliwie mocną stroną tego sektora. Założenie takiego przedsiębiorstwa, szczególnie z przedziału (0-9), jest relatywnie proste, nie wymaga wielkich nakładów finansowych, przynajmniej na początku działalności. 


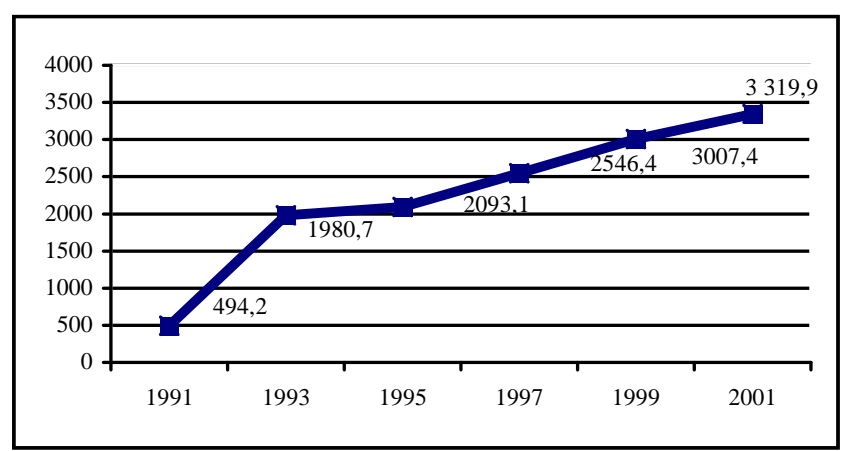

Wykres 1. Dynamika powstawania liczby przedsiębiorstw sektora MSP w latach 1991-2001

Źródło: Dane za lata 1991-1999; Instytut Wspierania Przedsiębiorstw; http://iwp.pl/material/k99_msp.htm; http://www.mg.gov.pl/struktur/WWW_MSP/Statystyka/MSP_Stat.htm; Kierunki działań rządu wobec małych i średnich przedsiębiorstw do 2002 roku; http://www.mg.gov.pl/struktur/WWW_MSP/Polityka/Polit_MS.htm; dane za rok 2001; Zmiany strukturalna grup podmiotów gospodarki narodowej w 2002r.,Główny Urząd Statystyczny, Warszawa, 2003, s. 50

W 2000 r. w rejestrze REGON figurowało 3319,9 tys. podmiotów. Jak na liczbę przedsiębiorstw jest to wartość imponująca. Nie jest ona jednak pozbawiona błędu. Należy zdawać sobie sprawę z faktu, iż wiele jednostek zarejestrowanych w tej bazie mogło wcale nie podjąć działalności, zawiesić ją, np. z powodu sezonowości, bądź działalność już dawno zakończyć nie wyrejestrowując jej z bazy. Dane te nie dają więc do końca prawdziwego obrazu sytuacji $\mathrm{w}$ tym zakresie. Wynika to $\mathrm{z}$ braku precyzyjnych uregulowań prawnych, nakładających na podmioty gospodarcze obowiązek wyrejestrowania $\mathrm{z}$ baz urzędowych niedziałającej już firmy, braku egzekwowania tego wymogu przez urzędy administracji państwa oraz braku poczucia obowiązku regulowania spraw urzędowych wśród obywateli. Powoduje to, iż w rejestrach mamy wartość obciążoną dużym błędem. Jest to o tyle niekorzystne, że przedstawia nieprawdziwy obraz sytuacji panującej na rynku, w tym przypadku liczbę przedsiębiorstw. Statystyki wyglądają imponująco, rzeczywistość jest dużo mniej zadowalająca. Relację między przedsiębiorstwami zarejestrowanymi a faktycznie działającymi w roku 2000 i 2001 przedstawiają tabele 2 i 3.

Dysproporcja pomiędzy liczbą przedsiębiorstw zarejestrowanych a aktywnych jest ogromna. W 2000 roku 55,5\% przedsiębiorstw z ogólnej liczby zarejestrowanych, tj. 1763 002, brało czynny udział w obrocie gospodarczym naszego kraju. Przypuszczać można, iż właśnie przedsiębiorstwa tego sektora płaciły podatki, dawały miejsca pracy, wypracowywały PKB itd. W 2001 roku już tylko 49,4\% przedsiębiorstw z ogółu zarejestrowanych brało udział w rynku, to znaczy, że 1693302 przedsiębiorstw z 3348124 ogółu było nieaktywnych. Spadek liczby przedsiębiorstw aktywnych świadczyć mógł o przejściowych trudnościach gospodarczych naszego kraju, powodem mógł być kryzys gospodarczy w Rosji i zmniejszenie eksportu na rynki wschodnie. Należy jednak oczekiwać stworzenia przez rząd takich rozwiązań, aby liczba zarejestrowanych podmiotów była liczbą faktycznie działających (aktywnych). 
Tabela 2. Liczba przedsiębiorstw zarejestrowanych oraz aktywnych w Polsce w $2000 \mathrm{r}$.

\begin{tabular}{|l|c|c|c|}
\hline \multicolumn{1}{|c|}{$\begin{array}{c}\text { Wielkość } \\
\text { przedsiębiorstwa }\end{array}$} & $\begin{array}{c}\text { Liczba } \\
\text { przedsiębiorstw } \\
\text { zarejestrowanych }\end{array}$ & $\begin{array}{c}\text { Liczba } \\
\text { przedsiębiorstw } \\
\text { aktywnych }\end{array}$ & $\begin{array}{c}\text { Udział przedsiębiorstw } \\
\text { aktywnych w liczbie } \\
\text { zarejestrowanych w (\%) }\end{array}$ \\
\hline $\begin{array}{l}\text { Małe (0-49 } \\
\text { zatrudnionych) }\end{array}$ & $\mathbf{3 1 4 7 ~ 0 5 9}$ & 1748775 & 55,5 \\
\hline $\begin{array}{l}\text { Średnie (49-249 } \\
\text { zatrudnionych) }\end{array}$ & 29102 & 14227 & 48,9 \\
\hline Razem sektor MSP & $\mathbf{3 1 7 6 ~ 1 6 1}$ & $\mathbf{1 7 6 3 0 0 2}$ & $\mathbf{5 5 , 5}$ \\
\hline $\begin{array}{l}\text { Duże (ponad 249 } \\
\text { zatrudnionych) }\end{array}$ & 6416 & 3071 & 47,8 \\
\hline Liczba ogółem & 3182577 & 1766073 & 55,5 \\
\hline
\end{tabular}

Źródło: Wach, Morawczyński 2003, s. 99-107

Tabela 3. Liczba przedsiębiorstw zarejestrowanych oraz aktywnych w Polsce w $2001 \mathrm{r}$.

\begin{tabular}{|l|c|c|c|}
\hline $\begin{array}{c}\text { Wielkość } \\
\text { przedsiębiorstwa }\end{array}$ & $\begin{array}{c}\text { Liczba } \\
\text { przedsiębiorstw } \\
\text { zarejestrowanych }\end{array}$ & $\begin{array}{c}\text { Liczba przedsiębiorstw } \\
\text { aktywych (oprócz rolnictwa, } \\
\text { leśnictwa, rybołówstwa } \\
\text { i rybactwa oraz } \\
\text { administracji publicznej) }\end{array}$ & $\begin{array}{c}\text { Udział przedsiębiorstw } \\
\text { aktywnych w liczbie } \\
\text { zarejestrowanych } \\
\text { w (\%) }\end{array}$ \\
\hline Sektor MSP & $\mathbf{3 3 4 8 ~ 1 2 4}$ & $\mathbf{1 6 5 4 \mathbf { 8 2 2 }}$ & $\mathbf{4 9 , 4}$ \\
\hline
\end{tabular}

Źródło: Raport o stanie sektora..., 2003, s. 29 i 31

\section{ZDOLNOŚĆ DO TWORZENIA NOWYCH MIEJSC PRACY}

Zwiększenie się liczby przedsiębiorstw w konsekwencji powoduje wzrost zatrudnienia. Znaczny wzrost liczby przedsiębiorstw MSP w latach 1991-2001 był jednym z głównych czynników ograniczających bezrobocie w naszym kraju. Firmy te przejmowały zatrudnienie z likwidowanych dużych zakładów pracy. Udział sektora MSP w liczbie pracujących w gospodarce (oprócz rolnictwa, leśnictwa, rybołóstwa i rybactwa) wzrósł z 55,7\% w 1993 r. do $68,2 \%$ w roku 2001, sytuację tą obrazuje tabela 4 i wykres 2 .

Tabela 4. Pracujący w sektorze MSP na koniec roku 2001

\begin{tabular}{|l|c|c|}
\hline \multicolumn{1}{|c|}{ Wielkość przedsiębiorstwa } & $\begin{array}{c}\text { Liczba pracujących } \\
\text { w tysiącach osób }\end{array}$ & Udział w \% \\
\hline Małe (0-49 zatrudnionych) & 4593,7 & 48,5 \\
\hline Średnie (49-249 zatrudnionych) & 2349,6 & 19,7 \\
\hline Razem sektor MSP & $\mathbf{6 9 4 3 , 3}$ & $\mathbf{6 8 , 2}$ \\
\hline Duże (ponad 249 zatrudnionych) & 3401,4 & 31,8 \\
\hline Liczba ogółem & 10344,7 & 100,0 \\
\hline
\end{tabular}

Źródło: Raport o stanie sektora..., 2003, s. 34 
Ten wysoki, bo ponad $68 \%$ w 2001 roku udział w liczbie pracujących przedstawiony na wykresie 2 sprawił, iż sektor MSP był i nadal jest (ponieważ te wahania nie są tak wielkie) największym pracodawcą w Polsce.

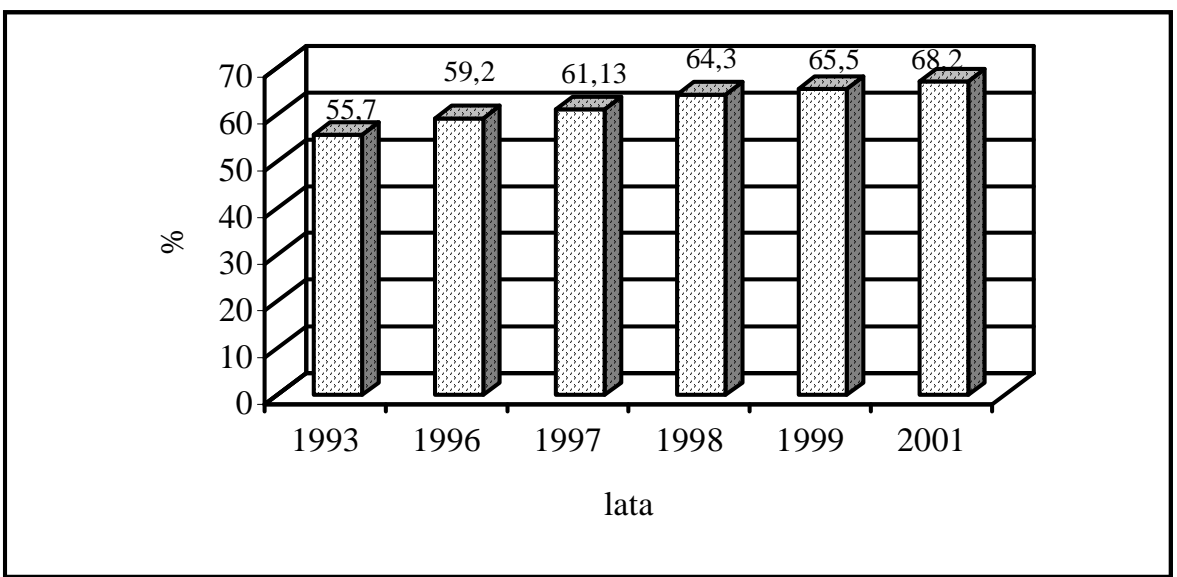

Wykres 2. Udział sektora MSP w liczbie pracujących w polskiej gospodarce w latach 1993-2001 (w \%)

Źródło: dane za lata 1993-1999: Kierunki dziatań rzqdu wobec małych i średnich przedsiębiorstw do 2002 roku; http://www.mg.gov.pl/struktur/WWW_MSP/Polityka/Polit_MS.htm; dane statystyczne dotyczące sektora MSP; http://www.mg.gov.pl/struktur/WWW_MSP/Statystyka/MSP_Stat.htm; Dane za rok 2001: Raport o stanie sektora..., Warszawa 2003, s. 34

Strukturę zatrudnienia w sektorze małych i średnich przedsiębiorstw obrazuje wykres 3 - warte uwagi jest to, iż spośród dziesięciu sekcji gospodarki największymi pracodawcami w sektorze MSP w 2001 roku były przedsiębiorstwa o handlowym i przemysłowym profilu działalności. Angażowały kolejno $32 \%$ oraz 29,9\% ogółu pracujących.

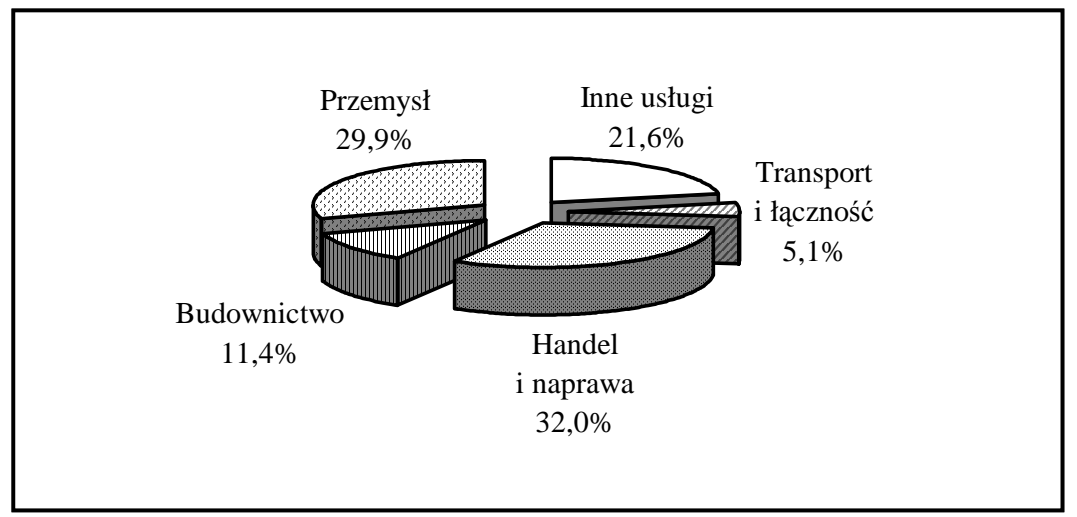

Wykres 3. Struktura pracujących w sektorze MSP. Stan na koniec 2001 roku w (\%) Źródło: Raport o stanie sektora..., 2003, s. 35 


\section{SYTUACJA FINANSOWA MAŁYCH I ŚREDNICH PRZEDSIĘBIORSTW}

Z badań, jakie przeprowadzono w ASM Centrum Badań Rynkowych, kondycja finansowa polskich MSP w latach 2000-2001 była niezadowalająca. Tylko 18\% badanych firm zanotowała wzrost zysków, natomiast $42,5 \%$ zanotowała ich spadek. Wykres 4 przedstawia przychody ze sprzedaży towarów i usług sektora MSP.

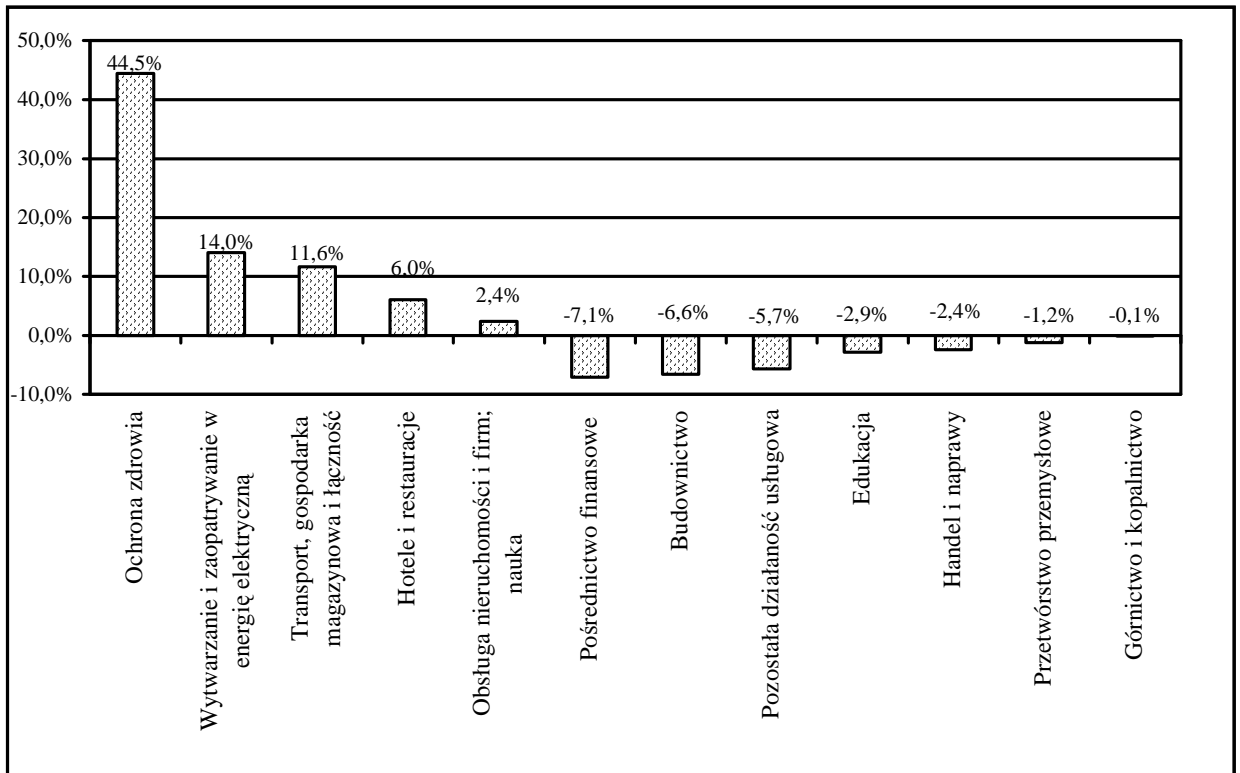

Wykres 4. Przychody przedsiębiorstw z sektora MSP ze sprzedaży produktów, towarów i usług z podziałem na sekcje w 2001 roku

Źródło: Raport o stanie sektora..., 2003, s. 42

Rozpatrując dwanaście powyższych sekcji gospodarki przychody przedsiębiorstw z sektora MSP w 2001 roku spadły w siedmiu z nich, a najwięcej w sekcji: pośrednictwo finansowe $(-7,1 \%)$, w budownictwie $(-6,6 \%)$, minimalnie w górnictwie $(-0,1 \%)$. Wzrost przychodów zanotowano w pięciu sekcjach, największy w ochronie zdrowia $(44,5 \%)$, wytwarzaniu i zaopatrzeniu w energię elektryczną gaz i wodę (14\%), transporcie $(11,6 \%)$, gospodarce magazynowej i łączności, hotelarstwie, obsłudze nieruchomości.

\section{UDZIAŁ SEKTORA MSP W PRZYCHODACH}

Udział sektora MSP w przychodach ze sprzedaży dóbr i usług przedsiębiorstw ogółem w latach 1999-2001, który obrazuje wykres 5, kształtował się na poziomie $63 \%$ do $64 \%$. W 2001 roku notowany był spadek do poziomu 63,8\% udziału, w tym przedsiębiorstwa zatrudniające do 49 osób miały wyższy, bo $43 \%$ udział tego sektora w przychodach. Zatrudniające od 49-249 miały tego udziału 20,8\%. 


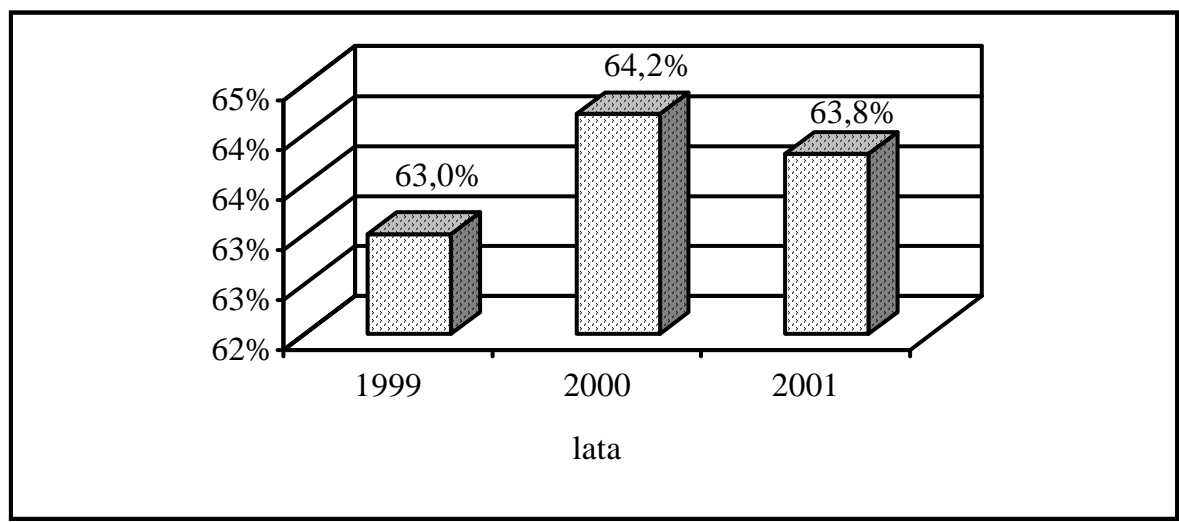

Wykres 5. Udział sektora MSP w przychodach ze sprzedaży dóbr i usług przedsiębiorstw ogółem w latach 1999-2001 w (\%)

Źródło: dane za rok 1999: Kierunki działań rzadu wobec matych i średnich przedsiębiorstw do 2002 roku; http://www.mg.gov.pl/struktur/WWW_MSP/Polityka/Polit_MS.htm; dane statystyczne dotyczace sektora MSP; http://www.mg.gov.pl/struktur/WWW_MSP/Statystyka/MSP_Stat.htm; dane za lata 2000-2001: Raport o stanie..., 2003, s. 42

\section{POZIOM NAKŁADÓW INWESTYCYJNYCH}

Prowadzenie działalności gospodarczej wiąże się z ciagłym poszukiwaniem środków finansowych dla podejmowanych inwestycji. MSP napotykają jednak na brak powszechnego dostępu do zewnętrznych źródeł finansowania. Brak odpowiednich unormowań prawnych oraz wysoki poziom ryzyka kredytowania tego typu przedsiębiorstw nie skłania banków do finansowania ich działań. Przedsiębiorstwa najczęściej finansują swoją działalność ze środków właścicieli oraz zysków. Ograniczenie dostępu do dogodnej formy finansowania działalności poważnie zawęża pole działania przedsiębiorców.

Udział sektora MSP w nakładach inwestycyjnych w sektorze przedsiębiorstw w latach 1993-1996 miał tendencję malejącą i wynosił w 1993 r. 38\%, a w 1996 r. 37\%. W 1998 r. udział wrósł do 44,2\%. W roku 2000 udział MSP w nakładach inwestycyjnych wzrósł do $50 \%$, ale już w roku 2001 ponownie spadł do nieco ponad 48\%. Poziom tych nakładów jest niski, wynika z tego, że polskie MSP mało inwestują. Zasadniczym powodem tej sytuacji mogą być trudności z uzyskaniem zewnętrznych źródeł finansowania.

Sposoby finansowania inwestycji, jakie wybierają małe i średnie przedsiębiorstwa, przedstawia wykres 7. Są to kolejno: środki własne-zyski firmy, kredyty bankowe, leasing, pożyczki od znajomych, rodziny i innych osób fizycznych, kredyty kupieckie, kredyty preferencyjne, sprzedaż majątku firmy, pożyczki z funduszy pożyczkowych, kredyty poręczeniowe przez fundusze poręczeń kredytowych, zakupy na raty, środki pomocowe. 


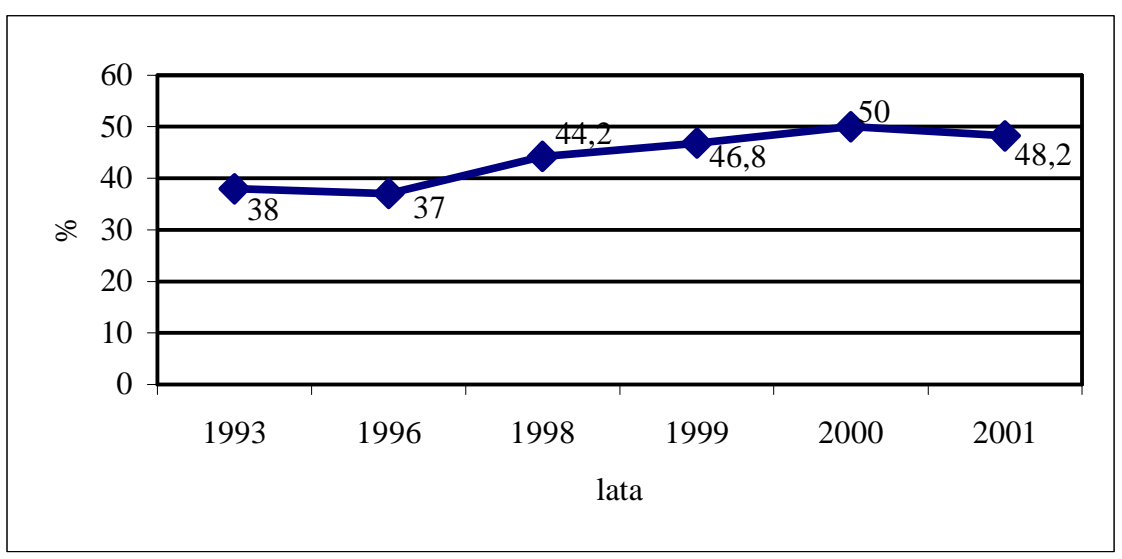

Wykres 6. Poziom nakładów inwestycyjnych w sektorze MSP w latach 1993-2001 w (\%)

Źródło: dane za lata 1993-1999: Kierunki działań rządu wobec małych i średnich przedsiębiorstw do 2002 roku; http://www.mg.gov.pl/struktur/WWW_MSP/Polityka/Polit_MS.htm; dane statystyczne dotyczace sektora MSP; http://www.mg.gov.pl/struktur/WWW_MSP/Statystyka/MSP_Stat.htm; dane za lata 2000-2001: Raport o stanie sektora..., 2003, s. 50

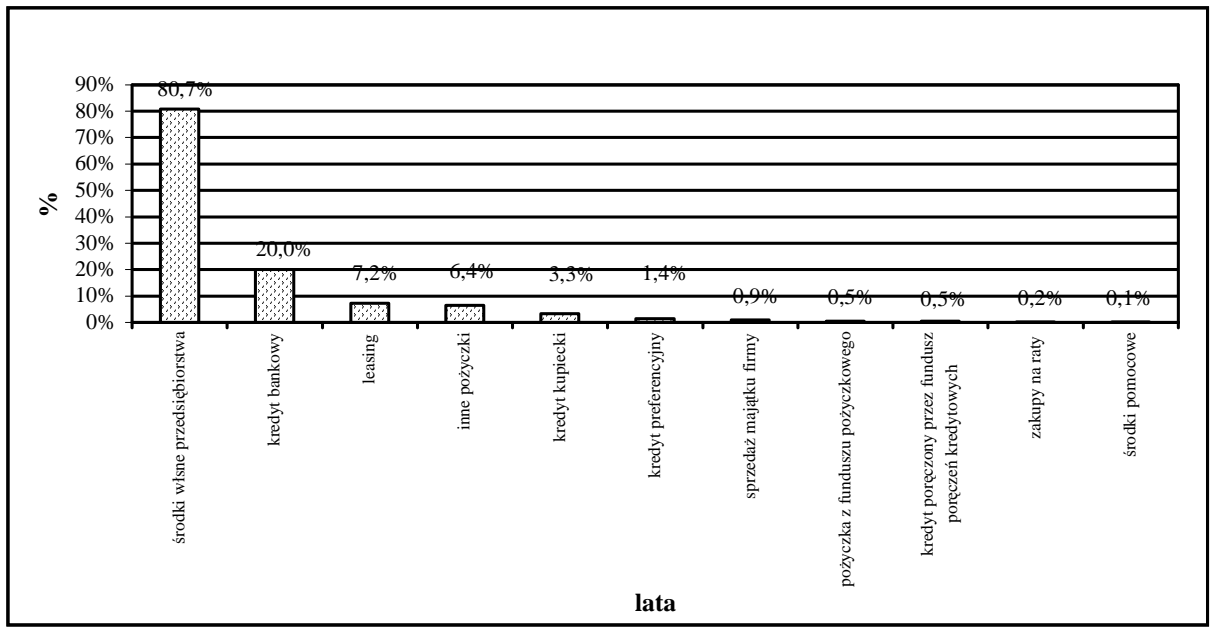

Wykres 7. Sposoby finansowania inwestycji w 2002 roku w (\%) Źródło: Raport o stanie sektora..., 2003, s. 53

Optymistyczny jest fakt, iż małe i średnie przedsiębiorstwa są w stanie generować i generują wewnętrzne źródła finansowania swojej działalności. Korzystniej byłoby, gdyby sytuacja taka stanowiła alternatywę do innych źródeł pozyskania środków finansowych, a nie konieczności. Gdyby np. kredyty w Polsce były tańsze, wyniki finansowe tych przedsiębiorstw mogłyby być lepsze. Niestety, polskie firmy uciekają się do zaciągania kredytów w bankach poza granicami naszego kraju, co jest prostą konsekwencją utrudnień i wysokich kosztów pozyskania środków finansowych z banków w kraju. Pociagga to za sobą wyprowadzenie zysków z oprocentowania kredytów zagranicę. Zależność ta prowadzi do sytuacji, iż nasze firmy podnoszą zyski bankom spoza granic Polski i utrzymują miejsca pracy również poza granicami kraju. 
Zastanawiający jest również bardzo niski udział sektora MSP w finansowaniu swojej działalności ze środków pomocowych. Przyczyną tego może być niedostępność tych źródeł lub słaba kampania informująca o możliwości ich pozyskania.

\section{ROLA MSP W HANDLU ZAGRANICZNYM}

Polskie przedsiębiorstwa z sektora MSP wykazują stosunkowo słabą, jak na swoje możliwości, aktywność na rynkach zagranicznych. Jak pokazują wartości na wykresie 8, udział małych i średnich firm w eksporcie stanowi sporo poniżej 50\%. Najlepszy pod tym względem był rok 1999, wartość ta wynosiła 47,7\% udziału MSP w eksporcie, później wartość ta zmniejszała się. Udział w eksporcie spadł w 2000 roku do 46,1\%, natomiast w 2001 roku jeszcze o $2,2 \%$ do $43,9 \%$. Spowodowane to było spadkiem koniunktury oraz wysokim kursem złotego.

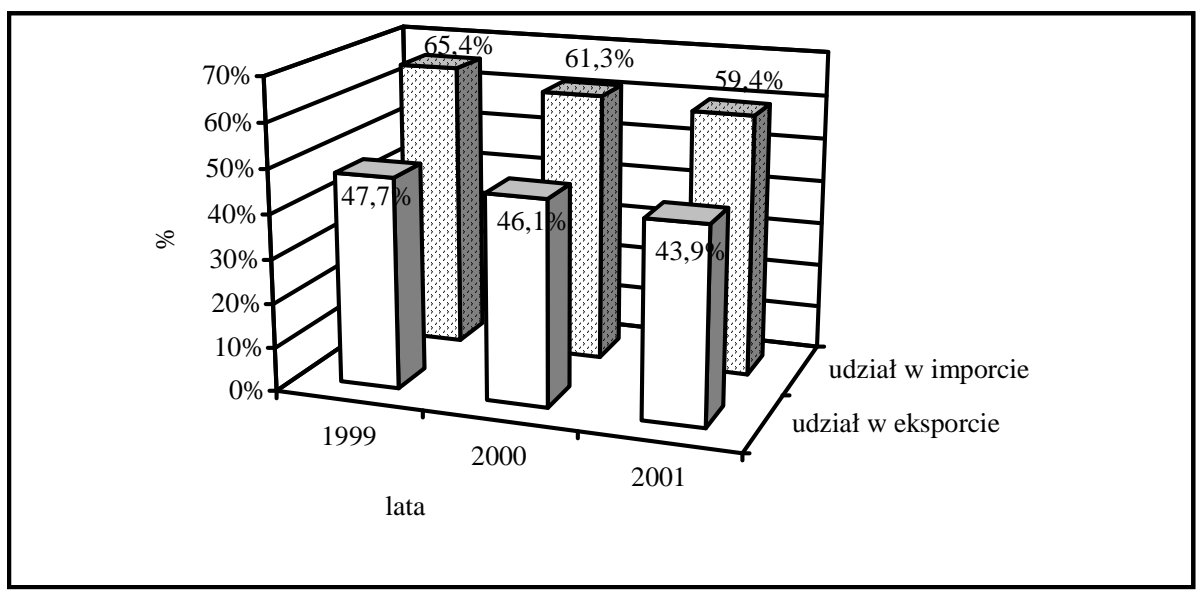

Wykres 8. Udział sektora MSP w eksporcie i imporcie ogółem w latach 1999-2001 w (\%)

Źródło: Raport o stanie sektora..., 2003, s. 57

Lepiej sytuacja wygląda w przypadku importu, chociaż i tu udział małych i średnich przedsiębiorstw również z roku na rok spada, z 65,4\% w 1999 roku do 59,4\% w 2001 roku. $\mathrm{Z}$ danych tych wynika, iż mamy do czynienia $\mathrm{z}$ wysokim, bo ponad $10 \%$ deficytem w obrotach handlowych z zagranicą. Dane te tym bardziej są niepokojące, iż geopolityczne położenie naszego kraju stwarza duże możliwości dla firm zorientowanych na współpracę zagraniczną.

Problematyczne jednak wydaje się być niemal całkowite przeniesienie uwagi przedsiębiorców z rynków wschodnich na zachodnie, gdzie trudniej jest konkurować. Konsekwencją tego jest mała aktywność firm polskich na rynkach byłego Związku Radzieckiego. Skłonność do eksportu wykazują tylko przedsiębiorstwa zlokalizowane w pobliżu granic państwowych (por. Piasecki 1998, s. 180-182). 
Znaczącą rolę w handlu zagranicznym Polski odgrywają przedsiębiorstwa spoza granic naszego kraju. Udział zagranicznych przedsiębiorstw w naszym eksporcie ogółem wyniósł w 2001 roku 51,8\%, z tego wynika, że ponad połowa polskiego eksportu realizowana jest przez przedsiębiorstwa zagraniczne, z tego 22,4\% czyli 1/4 przez MSP. Jeżeli chodzi o import, jak wynika $\mathrm{z}$ danych, również $\mathrm{w}$ większości jest realizowany przez przedsiębiorstwa zagraniczne. W 2001 roku ten udział wyniósł 60\% całego polskiego importu (Raport o stanie sektora..., 2003, s. 57. Wynika z tego, iż firmy zagraniczne importują blisko $10 \%$ więcej dóbr i usług niż ich eksportują. Wykresy 9. i 10. obrazują sytuację w eksporcie oraz imporcie w ujęciu poszczególnych sekcji gospodarki. Wynika z nich, że w polskim eksporcie i imporcie MSP dominuje przetwórstwo przemysłowe oraz handel i naprawy. Na obie te sekcje w roku 2001 przypadało $95 \%$ eksportu oraz $92 \%$ importu.

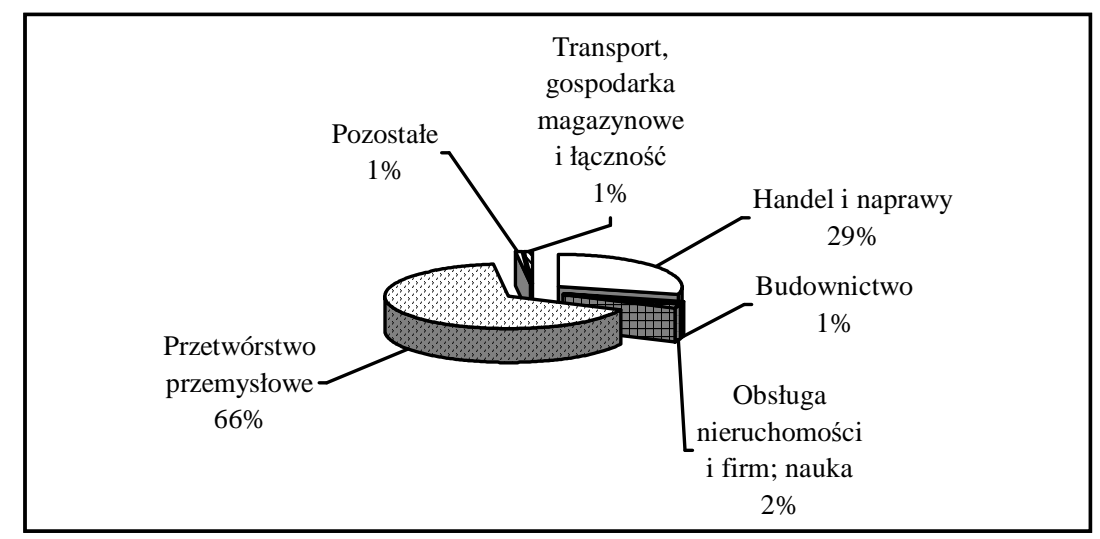

Wykres 9. Struktura eksportu MSP w poszczególnych sekcjach gospodarki w 2001 roku w (\%) Źródło: Raport o stanie sektora..., 2003, s. 58

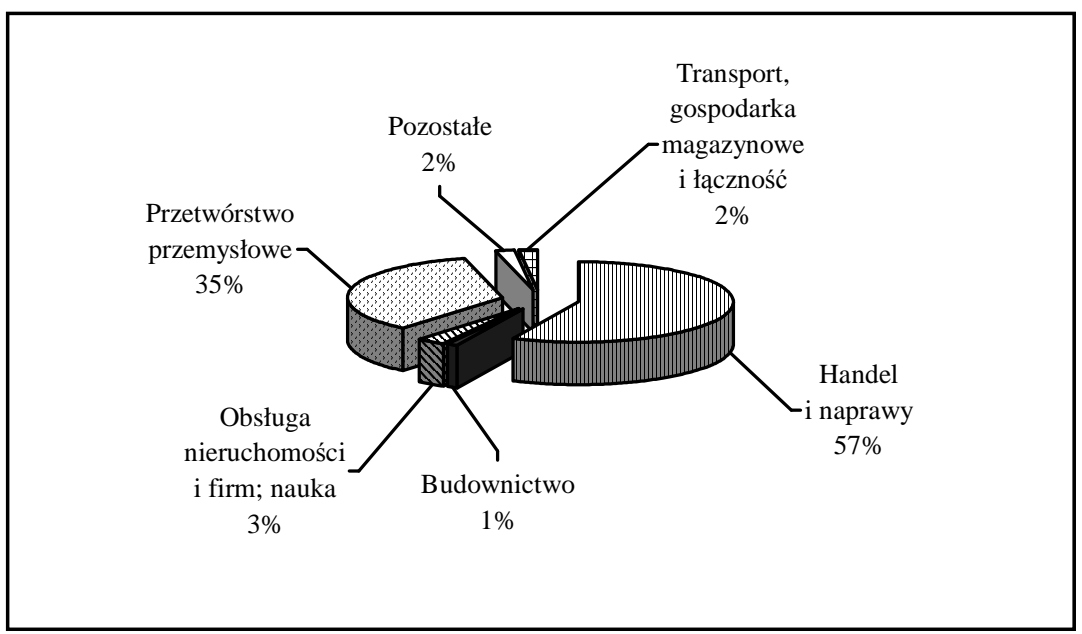

Wykres 10. Struktura importu MSP w poszczególnych sekcjach gospodarki w 2001 roku w (\%) Źródło: Raport o stanie sektora..., 2003, s. 58 
PODSUMOWANIE

Przedstawiony w artykule udział sektora MSP w gospodarce Polskiej w 2001 roku można syntetycznie zobrazować następującymi danymi statystycznymi:

Liczba MSP w tys.

3319,9

Udział MSP w gospodarce $\mathrm{w}(\%)$

99,8

68,2

Udział sektora MSP w liczbie pracujących w (\%)

$\begin{array}{ll}\text { Udział sektora MSP w przychodach ze sprzedaży dóbr i usług w (\%) } & 63,8 \\ \text { Poziom nakładów inwestycyjnych w sektorze MSP w (\%) } & 48,2\end{array}$

Udział sektora MSP w eksporcie ogółem w (\%) $\quad 43,9$

Udział sektora MSP w imporcie ogółem w (\%) 59,4

Analizując powyższe dane można stwierdzić, iż najwięcej przedsiębiorstw biorących udział w obrocie gospodarczym naszego kraju, to przedsiębiorstwa z sektora MSP. Ich udział w gospodarce wyniósł w roku 2001 ok. 99,8\%. Wartości te nie zmieniają się znacznie, można więc śmiało wnioskować, iż w latach obecnych niewiele się różnią. Polski sektor MSP jest największym pracodawcą w kraju, ale jak na swój bardzo wysoki udział w rynku angażuje relatywnie małą liczbę siły roboczej. Udział MSP w imporcie zdecydowanie przewyższa eksport, co wskazuje na to, iż przedsiębiorstwa te pogłębiają deficyt handlu zagranicznego naszego kraju. Udział w przychodach z prowadzonej działalności sektora MSP to niespełna 63\% ogółu przychodów w całej gospodarce. Duże przedsiębiorstwa, które stanowią zdecydowaną mniejszość, posiadają relatywnie wyższy udział w przychodach ze sprzedaży dóbr i usług.

Sektor małych i średnich przedsiębiorstw może być podstawą silnej gospodarki państwa, jednak należy mu stworzyć do tego odpowiednie warunki. Konieczna będzie skuteczna polityka rządu promująca rozwój tego sektora i wspomagająca pożądane kierunki jego ekspansji, natomiast położenie Polski na mapie geograficznej Europy może być tu zasadniczym czynnikiem wspomagającym. Przedsiębiorstwa polskie ze swoimi technologiami winny mocniej orientować swą działalność na rynki dawnego Związku Radzieckiego, jednocześnie umacniając pozycję w Unii Europejskiej poprzez wprowadzanie nowoczesnych technologii produkcji. Z nowymi technologiami łatwiej będzie konkurować na bardziej wymagających rynkach zachodnich. W momencie poszerzenia rynków zbytu wzrośnie produkcja oraz eksport, a co za tym idzie, można się spodziewać zwiększenia zatrudnienia. Firmy handlowe, które obecnie w większości prowadzą wymianę z krajami Unii Europejskiej, mają szansę odegrać istotną rolę, pośrednicząc w handlu pomiędzy Unią a krajami Europy Wschodniej. Warto jest umacniać ten sektor i kierować $\mathrm{w}$ jego stronę odpowiednią pomoc. W krajach wysoko rozwiniętych gospodarczo już się o tym przekonano, a sektor ten zyskał miano jednej z głównych sił stanowiących o ich gospodarczym rozwoju. 


\section{Literatura}

Piasecki B., 1998, Przedsiębiorczość i mała firma. Teoria i praktyka, Wydawnictwo Uniwersytetu Łódzkiego, Łódź

Raport o stanie sektora matych i średnich przedsiębiorstw w Polsce w latach 2001-2002, 2003, red. A. Rybińska, A. Tokaj-Korzewska, PARP, Warszawa

Strona internetowa Instytutu Wspierania Przedsiębiorstw:

http://iwp.pl/material/k99_msp.htm

Strony internetowe Ministerstwa Gospodarki:

http://www.mg.gov.pl/struktur/WWW_MSP/Polityka/Polit_MS.htm

http://www.mg.gov.pl/struktur/WWW_MSP/Statystyka/MSP_Stat.htm

Wach K., Morawczyński R., 2003, Impact of the EU accession on Polish small and medium-sized enterprises, [w:] Small and medium enterprises in European economies, International Conference Procedings, Babes-Bolyai University Cluj Napoca, Faculty of Business, Romania, Editura Alma Mater

Wielgus G., 2002, Formy wspierania matych i średnich przedsiębiorstw (MSP) i ich rola w gospodarce, Zarzqdzanie firma - teoria i praktyka. Materiaty pokonferencyjne z IV Międzynarodowej Konferencji Naukowej, Wydział Zarządzania Akademii Górniczo-Hutniczej, Kraków

Zmiany strukturalna grup podmiotów gospodarki narodowej w 2002 r., 2003, GUS, Warszawa 